\title{
Blockholder Ownership as Governance Mechanism on Firm Performance: Evidence From Malaysia
}

\author{
Ahmad Ibn Ibrahimy ${ }^{1} \&$ Rubi Ahmad $^{2}$ \\ ${ }^{1}$ Department of Accounting and Finance, University Malaysia Sarawak, Sarawak, Malaysia \\ ${ }^{2}$ Department of Finance and Banking, University Malaya, Malaysia \\ Correspondence: Department of Accounting and Finance, University Malaysia Sarawak, 94300 Kota Samarahan, \\ Sarawak, Malaysia.
}

Received: December 19, 2019

Accepted: January 20, 2020

Online Published: January 31, 2020

doi:10.5430/ijba.v11n1p27

URL: https://doi.org/10.5430/ijba.v11n1p27

\begin{abstract}
We examined the relationship between blockholder ownership and firm performance in the context of high concentrated ownership in Malaysia coupled with weak regulatory framework. Blockholder ownership is used as monitoring device to verify the significant role in managerial decisions accordance with maximizing shareholders' wealth. Consequently, blockholders may have personal incentive to the expropriation of minority shareholders' wealth by exercising their corporate control. We found a positive significant relationship with small effect of beta coefficients by both market and accounting based measurements. The positive relationship of blockholders as institutions is the conformity of monitoring hypothesis. The results indicate a very week monitoring impact of blockholders on executives' decisions that improve the firm performance by reducing the agency costs. Additionally, the significant low positive effect of profit volatility is representing the efficacy of blockholders until a certain level.
\end{abstract}

Keywords: agency cost, blockholder ownership, corporate control, corporate governance, firm value, Malaysia, ownership concentration, panel data analysis

\section{Introduction}

The current research direction on incentive makes it necessary to examine the effectiveness of corporate governance reform in a country which depends on the distinct countrywide business systems (Pedersen \& Thomsen, 1999). Jensen \& Meckling (1976) relate agency theory to modern corporation and form relative amount of ownership claims held by insiders and outsiders. Insiders are the management, and outsiders refer to the investors with no direct role in the management of a corporation. They formalize the survival of organizations by "separation of ownership and control." Shareholders experience a loss of control over their resources to oversee managerial activities in modern corporations. Management exercises more freedom rather if at least ownership is concentrated or firm is managed by its owners. Recently, this image of one run by professional managers without accountability to shareholders clearly stuck. There are some evidences of concentrated ownership existence around the world. Shleifer \& Vishny (1986) demonstrated that there is a modest ownership concentration even in largest American firms. Since management and ownership usually do not coincide, Berle \& Means (1932) perceived a conflict of interests between parties. Studies by Hartzell \& Starks (2003) found that blockholders could be an efficient control mechanism to align the interests between stakeholders. When share is more concentrated, atomistic shareholders get priority to co-ordinate and demand information from management. On the other hand, when share is diffusely held among investors, the information asymmetries are greater between managers and the shareholders. Therefore, it is more difficult for shareholders to gauge the managerial action whether they are acting for their best interests. This inability may lead the managers to pursue their own interests rather than maximizing shareholders' wealth. Therefore, outside blockholders can play an important role of minimizing the deviation of interests between managers and shareholders as they can monitor the managers closely.

Malaysian corporate sector is characterized by concentrated ownership (Haniffa \& Hudaib, 2006), pyramid structure, cross-holding; and sometimes with dual class shares (Note 1) that well-defined in family controlled firms (Claessens et al., 2000). Managers usually come from the same family of large controlling shareholders where managers (agents) and shareholders (principals) conflicts of interests are limited. According to Zhuang (2001), Asian countries are characterized by concentrated ownership and weak regulatory structure leading to a weak corporate governance 
setting. With the implementation of interest alignment mechanisms; the developing markets including Malaysia are characterized by an insider system of corporate governance. However, Haniffa \& Hudaib (2006) found Malaysian corporate firms are conquered by undiluted family shareholding firms over time. These findings suggest evidence of ownership concentration in Malaysian corporate sectors. As blockholders regularly monitor the management (Holderness, 2003), the stability of blockholders essentially have a significant role in managerial decisions (Shleifer \& Vishny, 1986). The efficient management or the blockholders, thereby ensure both controlled and dispersed shareholders of their returns to increase shareholders' value (De Andres et al., 2005). Large shareholding can be seen exclusively among individuals or organizations for the shared benefits of control and the private benefits of control. In the presence of weak corporate governance in Asian countries (Zhuang, 2001) and presence of concentrated ownership (Haniffa \& Hudaib, 2006) in Malaysia, this study deals with blockholder ownership as corporate governance mechanism that affects firm value. To investigate whether there is any significant relationship between blockholder ownership and firm value we used both market and accounting based performance measurements.

\section{Literature Review}

Basically, there are three questions arises about (i) block sellers' premium over exchange price (ii) block sellers' transfer facilitation and (iii) block purchasers' buying options (Barclay \& Holderness, 1992). These issues have been investigated since Berle \& Means (1932) and there is a persistent belief that minority shareholders are injured by large block trades. Barclay \& Holderness (1992) examined the strength of this belief by analyzing at least $5 \%$ of the blockholders of the listed companies and their findings contradict (i) many calls for legislation that require allocation of control premiums with minority shareholders (ii) prohibit the contracts that facilitate block sellers transfer options.

There is controversy among academician as well as regulators regarding the large percentage of blockholders' trades in public listed companies. Minguez-Vera \& Martin-Ugedo (2007) analyzed the influence of blockholder ownership on firm value using endogenous treatment and found a positive relationship between major shareholders and firm performance. Prowse (1992) used Japanese data on shareholding to observe how the structure and concentration of shareholding differ with other firm characteristics. With the distinctive corporate governance practices in Japan by independent and Keiretsu groups, they found a positive relationship between concentrated ownership and the stock returns within independent firms of highly controlled management. They also found that there is no relation between ownership concentration and accounting profit of both independent and the Keiretsu group. Besides, Bethel et al. (1998) explored the causes and consequences of activist block share purchases and found that activist blockholders are investing in well diversified firms with poor profitability. They documented that market for partial corporate control reducing agency costs through activist (Note 2) block purchases followed by the increases asset divestiture, decreases in merger and acquisition and abnormal share price appreciation. Renneboog (2000) related the corporate governance mechanisms such as blockholders, market for partial control, debt policy and board composition with poor performance to examine how corporate control is affecting in companies listed on the Brussels Stock Exchange. They found that top management turnover is strongly related with poor performance. Agrawal \& Mandelker (1990) looked into the role of block shareholders in monitoring managers when they propose these amendments. With the distinctive aspects of 'active monitoring hypothesis' and 'passive voting hypothesis' they found a positive significant relationship between the blockholders and the shareholders wealth effects. Their findings support the 'active monitoring hypothesis' that blockholder ownership leads to better monitoring of managers.

Hartzell \& Starks (2003) measured the influence of institutional investors through their ownership concentration in firms and found a negative relation to the level of executive compensation. This study recommends that institutions play a monitoring role in reducing the agency conflicts between managers and shareholders. Burkart et al., (1997) explained the trade-off between managerial discretion and the incentive of large outside shareholders to monitor the managers. By challenging the notion of reduction of managerial discretion, they raised some robustness issues. First, a huge monetary compensation is needed to align the interests between insiders and outsiders when insiders gain huge private benefits from discretion. Second, the further purchasing of a block increases shareholders' wealth when managerial discretions are sunk provided the dispersed shareholders do not retain their shares. Additionally, the empirical literature proved that new large shareholders lead the share price increase which benefits other shareholders of the company (Zeckhauser \& Pound, 1990). Nevertheless, this benefits are most favorable when the large shareholders trying to capture the control of the target company. Eventually, acquired company falls into takeover pressure as new blockholders appear rather than their engagement in monitoring that benefits the company. Slovin \& Sushka (1993) explored how ownership concentration affect firm performance and control of US firms by examining obituary notices published in the Wall Street Journal. On the effects of death of inside blockholders, their findings reveal the negative relation of shareholder's wealth increases and ownership concentration decreases with extensive corporate control develops. In other words, they found the positive relation between stock price and the 
death of inside blockholders. Cronqvist \& Nilsson (2003) estimated the agency costs of controlling minority shareholders using a panel data of Swedish firms. The evidence showed a negative relation between firm performance and different categories of controlling shareholders ranging the agency costs of $6 \%$ to $25 \%$.

Malaysian business environment is different from that of US or UK in many respects. First, there is a high ownership concentration compare to other countries in Asia (Claessens, et al., 2000). Haniffa \& Hudaib (2006) found their mean of large five shareholders is $62 \%$. This implies that the protection of minority shareholders in Malaysia may be weakened. It also refers to the weak market of corporate control to discipline the managers. Second, there are no separation between blockholders and the managers due to close control by blockholders or owners who are often from the same family. This implies the increasing risk of minority shareholders' wealth expropriation. Third, Malaysian companies are often characterized by cross-holding or pyramiding ownership structures. Chu \& Song (2011) examined the interaction effects of blockholders, leverage and diversification of Malaysian manufacturing firms and found that blockholders are negatively related to firm value through diversification. But there is no proof of controlling shareholder causing excessive borrowing for diversification. Claessens et al. (2000) studied the ownership structure effect to firm performance and found the blockholders having a significant impact on performance in Malaysia. They also found that coupled with the influence on business operations, most blockholders are having a seat (or proxy) in Board of Directors. On the other hand, Ngui \& Voon (2008) examined the relationship between outside blockholders and firm performance of Malaysian firms using a single structural model and found a negative relationship. Two types of ownership concentration are applied in the study, insider ownership and outside blockholders. Blockholders' negative effect on firm performance indicates that expectation of blockholders alleviate the managerial (insiders) entrenchment. According to Yeo et al. (2002), existence of major blockholders can be an effective monitoring mechanism on managerial incentives when there is a low level of managerial ownership. In regard to the relationship between blockholders and the performance of the company, US based study found no systematic relationship. Thomsen et al. (2006) found a negative relation between blockholders and firm performance in Continental Europe where ownership concentration is high. They report this result as facts of conflicts of interest between blockholders and minority investors. In the case of Malaysia, where ownership concentration is higher (Claessens, et al., 2002) compare to US or UK and the investors' protection is lower, blockholders may have different aspect on firm performance.

\section{Methodology and Data}

Burkart et al. (1997) proposed that blockholders may have positive effect on firm value because they might be more efficient monitors of managers than atomistic shareholders. A higher market price leads to higher level of investment (La Porta et al., 2000) if blockholders hold strong incentives to maintain their control in firms by owning the larger amount shares of higher value companies. On the other hand, there might be a negative effect on the firm value (Bebchuk \& Roe, 1999) because blockholders may conspire with managers against the atomistic shareholders. In addition, they may sell shares when the price is high (Zeckhauser \& Pound, 1990) may due to absolute risk and opportunity costs by owning additional stakes of shares. Based on these arguments, either positive or negative relationship is expected between blockholder ownership and firm performance.

Following Thomsen et al. (2006), the main issue of this study is to identify whether blockholders of the companies contributing to the firm performance. This is a panel data analysis of sample companies using regression equation. To detect the multicollinearity problem of explanatory variables, Pearson simple correlation test is performed. Blockholders are defined as shareholders who own 5\% of shares and above (Thomsen et al., 2006), otherwise 1. To develop the models that will identify how blockholder ownership may have influence on firm performance after controlling firm specific variables, panel data specifications with pooled OLS and GLS models are used. The empirical relationships for both market based and accounting based performance measures of firm $i$ in the year $t$ are given bellow:

$$
\begin{gathered}
\mathrm{TQ}_{\mathrm{it}}=\alpha+\beta_{1} \mathrm{BL}_{\mathrm{it}}+\beta_{2} \mathrm{PV}_{\mathrm{it}}+\beta_{3} \mathrm{DR}_{\mathrm{it}}+\beta_{4} \mathrm{G}_{\mathrm{it}}+\beta_{5} \mathrm{~S}_{\mathrm{it}}+\mathrm{u}_{\mathrm{it}} \\
\mathrm{ROE}_{\mathrm{it}}=\delta+\lambda_{1} \mathrm{BL}_{\mathrm{it}}+\lambda_{2} \mathrm{PV}_{\mathrm{it}}+\lambda_{3} \mathrm{DR}_{\mathrm{it}}+\lambda_{4} \mathrm{G}_{\mathrm{it}}+\lambda_{5} \mathrm{~S}_{\mathrm{it}}+\mathrm{u}_{\mathrm{it}}
\end{gathered}
$$

Where,

$\mathrm{TQ}=$ Tobin's $\mathrm{Q}$

$\mathrm{ROE}=$ Return on Equity

$\mathrm{BL}=$ Blockholder Ownership

$\mathrm{PV}=$ Profit Volatility 
DR $=$ Debt Ratio (Leverage)

$\mathrm{G}=$ Growth of the Company

$\mathrm{S}=$ Size of the Company

The study covers 1407 observations of 201 non-financial Malaysian listed companies to observe the relationship between firm performance and blockholder ownership. The historical or secondary data are used for the period of 2002 to 2008. In sourcing for the data to be chosen, ownership data were extracted directly from the respective annual reports. Seven years period is chosen to capture the true picture concerning the movement of company's performance especially after Asian financial crisis of 1997-1998. While data for the regression variables are gathered from Bloomberg and Data Stream Databases.

\section{Findings and Analyses}

This study focuses on the impact of blockholder ownership on firm performance. In order to visualize this scenario, it is necessary to satisfy one of the Classical Linear Regression Model (CLRM) assumptions, multicollinearity (Stevens, 2002). To ensure that all explanatory variables are independent, Table 1.0 shows the results of simple correlation between independent variables. It is found that firm's size is positively related with blockholder ownership, debt ratio and growth; and they are significant at $1 \%$ significance level. These variables are correlated by $17 \%, 23 \%$ and $16 \%$ respectively which is much lower than the benchmark of allowing the relation of $80 \%$ (Gujarati, 2003). Other significant correlations among variables are even smaller which doesn't cause the multicollinearity problem. Combination of cross section and time-series data, the extra variations set up by panel data also help to alleviate multicollinearity problem (Brooks, 2008).

Table 1. Simple correlation of blockholder ownership and firm performance

\begin{tabular}{llllll}
\hline & Block & Profit Volatility & Debt Ratio & Growth & \\
\hline Block & 1.00 & & & \\
\hline Profit Volatility & 0.02 & 1.00 & & \\
\hline Debt Ratio & $-0.10^{* * *}$ & $0.15^{* * *}$ & 1.00 & 1.00 \\
\hline Growth & 0.01 & 0.01 & 0.01 & $0.16^{* * * *}$ \\
\hline Size & $0.17^{* * *}$ & -0.01 & $0.23^{* * * *}$ & \\
\hline *** Significant at $1 \%$ level & & & & \\
\hline
\end{tabular}

*** Significant at $1 \%$ level

\subsection{Blockholder Ownership Effects on Firm's Performance}

While large blockholders is prevalent in Malaysian Economy (Claessens \& Fan, 2002), our main objective is to focus on the influence of blockholder ownership on firm performance to explore the consequences and the benefits.

\subsubsection{Results of Blockholder Ownership Effects With Tobin's q (TQ)}

Table 2 is the results of both OLS and GLS estimations to test the effect of blockholder ownership on firm performance (TQ). Results of two estimators are reported in order to compare the estimations. We found that blockholer is positively significant at 5\% level by pooled OLS estimator. This positive significant relationship of OLS estimator may represent a little influence of blockholders in managerial decisions of Malaysian listed companies. Though pooled OLS estimation is positively significant but it reveals very small effects of beta coefficient. On the other hand, dispersed ownership causes the investors loosing the monitoring ability of management; therefore, blockholder ownership would have positive effect on firm performance. This result overall indicates that blockholder ownership does have little influence on firm performance that reduces agency costs as a governance mechanism. We found this blockholders as institutions. The positive relation of blockholder ownership is 
supporting the monitoring hypothesis. This finding is similar to Minguez-Vera \& Martin-Ugedo (2007) but contrast with Chu \& Song (2011) for Malaysian manufacturing firms.

Table 2. Pooled OLS and GLS estimations of blockholders against TQ

\begin{tabular}{|c|c|c|}
\hline Against TQ & \multirow{2}{*}{$\begin{array}{l}\text { Pooled } \\
\text { OLS }\end{array}$} & \multirow{2}{*}{$\begin{array}{l}\text { Pooled } \\
\text { GLS }\end{array}$} \\
\hline Variables & & \\
\hline Intercept (C) & -0.15 & $-0.32 * *$ \\
\hline Blockholder (BL) & $0.001 * *$ & 0.0005 \\
\hline Profit Volatility (PV) & $0.05 * * *$ & $0.04 * * *$ \\
\hline Debt Ratio (DR) & $-0.007 * * *$ & $-0.003 * * *$ \\
\hline Growth $(\mathrm{G})$ & $0.002 * * *$ & $0.002 * * *$ \\
\hline Size (S) & $0.05 * * *$ & $0.06 * * *$ \\
\hline $\mathbf{R}^{2}$ & 0.19 & 0.41 \\
\hline Adjusted $\mathrm{R}^{2}$ & 0.19 & 0.40 \\
\hline F-statistic & $67.67 * * *$ & $191.12 * * *$ \\
\hline D-W statistic & 0.73 & 0.96 \\
\hline
\end{tabular}

*** $1 \%$ Significant level $* * 5 \%$ Significant level $* 10 \%$ Significant level

The risk level is assessed by profit volatility which is positively significant for both OLS and GLS estimators at $1 \%$ significance level. While high profit insists close monitoring by owners, this variable is incorporated in the model to gauge the instability of managerial actions to reflect year to year fluctuations in underlying business conditions. The low positive effect of profit volatility is indicating the efficiency of monitoring by blockholders until a certain level. For both estimations, debt ratio, growth and firm size are statistically significant at $1 \%$ level where leverage is inversely related with firm performance. In addition, firm's growth and size are positively related with firm performance. Among the estimators, pooled GLS model has higher explanatory power.

\subsubsection{Results of Blockholder Ownership Effects With Return on Equity (ROE)}

The study also used Return on Equity (ROE) as alternative measurement of firm performance. This accounting performance measurement (ROE) is applicable as it is informative to study whether the performance of executives results in increasing wealth of shareholders. Table 3 shows the results of both pooled OLS and GLS regression estimations of blockholder ownership through the years to test the monitoring or incentives effects of blockholders on firm performance (ROE). Results of two estimators are reported in order to compare the estimations. For both pooled estimations, blockholder is positively significant with firm performance which is the conformity of previous section finding. Overall, this positive relationship is indicating a modest link of blockholders with firm performance. This result is similar with Haniffa \& Hudaib (2006) but contrasts with Ngui \& Voon (2008) of Malaysian firms.

Table 3. Pooled OLS and GLS estimations of blockholders against ROE

\begin{tabular}{lll}
\hline Against ROE & $\begin{array}{l}\text { Pooled } \\
\text { OLS }\end{array}$ & $\begin{array}{l}\text { Pooled } \\
\text { GLS }\end{array}$ \\
\hline Intercept $\odot$ & $-58.76^{* * *}$ & $-36.18^{* * *}$ \\
\hline Blockholder $(\mathrm{BL})$ & $0.03 *$ & $0.03 * * *$ \\
\hline
\end{tabular}




\begin{tabular}{|c|c|c|}
\hline Profit Volatility (PV) & -0.49 & $0.60 * * *$ \\
\hline Debt Ratio (DR) & $-0.23 * * *$ & $-0.15 * * *$ \\
\hline Growth $(\mathrm{G})$ & $0.11 * * *$ & $0.11 * * *$ \\
\hline Size $(\mathrm{S})$ & $3.49 * * *$ & $2.12 * * *$ \\
\hline $\mathbf{R}^{2}$ & 0.17 & 0.40 \\
\hline Adjusted $\mathrm{R}^{2}$ & 0.17 & 0.39 \\
\hline F-statistic & $58.87 * * *$ & $183.83 * * *$ \\
\hline D-W statistic & 1.20 & 1.15 \\
\hline
\end{tabular}

Among control variables, profit volatility found to have significant positive relationship with firm performance by pooled GLS estimator. Debt ratio, growth and firm size are statistically significant at $1 \%$ level by both estimators where leverage (debt ratio) is inversely related with firm performance. In terms of goodness of fit of the models, pooled OLS regression exhibits low $\mathrm{R}^{2}$ compared to GLS regression estimator.

\section{Conclusion}

The majority of the developed markets are characterized by agency conflicts between managers and the shareholders. Unlike developed markets, emerging markets are prone to have agency conflicts between majority and minority shareholders. Most of the East Asian corporations are mainly controlled by a single large shareholder (Rafael, et al., 1999) and/or by concentrated owners (Haniffa \& Hudaib, 2006). This concentrated ownership has strong incentives to supervise the managers and gather information that eventually maximize the shareholders' wealth (Jensen \& Meckling, 1976). On the contrary, large shareholders have incentives to expropriate minority shareholders wealth (Claessens \& Fan, 2002) through proxy fight or takeover (Shleifer \& Vishny, 1997).

The main objective of this study is to determine the impact of blockholder ownership as corporate governance mechanism on firm performance while considering both market based (TQ) and accounting based (ROE) measures of performance. Study found that blockholder ownership is positively significant with low magnitude of coefficients by both measurements. The positive relationship is indicating the blockholders as monitoring device with modest power by reducing the agency costs which in line with monitoring hypothesis. It means that monitoring of managers is an increasing function of blockholder ownership. This outcome is also indicating the likelihood of hidden motives by blockholders in Malaysian economy. Notably, there is a probability of expropriating minority shareholders' wealth by blockholders. Units of corporate sector or managers can design their policies based on the evidences. At the macro level, the findings would be of interest of corporate regulators. Academicians will be also benefitted from the suggestions of exploring the relationship between governance mechanism and firm performance in Malaysia. Consequently, the Malaysian Code on Corporate Governance (MCCG) will be directly improved.

In this study the focus has been on the effect of blockholder ownership as monitoring mechanism to reduce agency problem. Analyses of other alignment mechanisms such as effectiveness of board of directors, market for corporate control are not considered. Study could be extended applying interaction effect of blockholder ownership with firm size. Future studies could use the tax implication and financial reporting issues for using blockholders' effects on firm performance.

\section{References}

Agrawal, A., \& Mandelker, G. N. (1990). Large Shareholders and the Monitoring of Managers: The Case of Antitakeover Charter Amendments. Journal of Financial and Quantitative Analysis, 25(2), 143-161. https://doi.org/10.2307/2330821

Barclay, M. J., \& Holderness, C. G. (1992). The Law and Large-block Trades. Journal of Law and Economics, 35(2), 265-294. https://doi.org/10.1086/467254

Bebchuk, L. A., \& Roe, M. J. (1999). A Theory of Path Dependence in Corporate Ownership and Governance. 
Stanford Law Review, 52(1), 127-170. https://doi.org/10.2307/1229459

Berle, A. A., \& Means, G. C. (1932). The Modern Corporation and Private Property. New York: McMillan.

Bethel, J. E., Liebeskind, J. P., \& Opler, T. (1998). Block Share Purchases and Corporate Performance. Journal of Finance, 53(2), 605-634. https://doi.org/10.1111/0022-1082.244195

Brooks, C. (2008). Introductory Econometrics for Finance. Cambridge University Press. https://doi.org/10.1017/CBO9780511841644

Burkart, M., Gromb, D., \& Panunzi, F. (1997). Large Shareholders, Monitoring, and the Value of the Firm. Quarterly Journal of Economics, 112(3), 693-728. https://doi.org/10.1162/003355397555325

Chu, E., \& Song, S. (2011). Large Shareholders, Capital Structure and Diversification of Malaysian Public Listed Manufacturing Firms. African Journal of Business Management, 5(14), 6005-6010.

Claessens, S., \& Fan, J. P. H. (2002). Corporate Governance in Asia: A Survey. International Review of Finance, 3(2), 71-103. https://doi.org/10.1111/1468-2443.00034

Claessens, S., Djankov, S., \& Lang, L. H. P. (2000). The Separation of Ownership and Control in East Asian Corporations. Journal of Financial Economics, $58(1-2), \quad$ 8112. https://doi.org/10.1016/S0304-405X(00)00067-2

Claessens, S., Djankov, S., Fan, J. P. H., \& Lang, L. H. P. (2002). Disentangling the Incentive and Entrenchment Effects of Large Shareholdings. Journal of Finance, 57(6), 2741-2771. https://doi.org/10.1111/1540-6261.00511

Cronqvist, H., \& Nilsson, M. (2003). Agency Costs of Controlling Minority Shareholders. Journal of Financial and Quantitative Analysis, 38(4), 695-719. https://doi.org/10.2307/4126740

De Andres, P., Azofra, V., \& Lopez, F. (2005). Corporate Boards in OECD Countries: Size, Composition, Functioning and Effectiveness. Corporate Governance: An International Review, 13(2), 197-210. https://doi.org/10.1111/j.1467-8683.2005.00418.x

Gujarati, D. N. (2003). Basic Econometrics (4th ed.). New York: McGraw-Hill Higher Education.

Haniffa, R., \& Hudaib, M. (2006). Corporate Governance Structure and Performance of Malaysian Listed Companies. Journal of Business Finance \& Accounting, 33(7-8), 1034-1062. https://doi.org/10.1111/j.1468-5957.2006.00594.x

Hartzell, J. C., \& Starks, L. T. (2003). Institutional Investors and Executive Compensation. Journal of Finance, 58(6), 2351-2374. https://doi.org/10.1046/j.1540-6261.2003.00608.x

Holderness, C. G. (2003). A Survey of Blockholders and Corporate Control. Economic Policy Review, 9(1), 51-64.

Jensen, M. C., \& Meckling, W. H. (1976). Theory of the Firm: Managerial Behavior, Agency Costs and Ownership Structure. Journal of Financial Economics, 3(4), 305-360. https://doi.org/10.1016/0304-405X(76)90026-X

La Porta, R., Lopez-de-Silanes, F., Shleifer, A., \& Vishny, R. (2000). Investor Protection and Corporate Governance. Journal of Financial Economics, 58(1-2), 3-27. https://doi.org/10.1016/S0304-405X(00)00065-9

Minguez-Vera, A., \& Martin-Ugedo, J. F. (2007). Does Ownership Structure Affect Value? A Panel Data Analysis for the Spanish Market. International Review of Financial Analysis, 16(1), 81-98. https://doi.org/10.1016/j.irfa.2005.10.004

Ngui, K. S., \& Voon, M. L. (2008). Ownership Concentration and Performance of Malaysian Listed Firms. Retrieved from http://ssrn.com/abstract=1101222

Pedersen, T., \& Thomsen, S. (1999). Economic and Systemic Explanations of Ownership Concentration Among Europe's Largest Companies. International Journal of the Economics of Business, 6(3), 367-381. https://doi.org/10.1080/13571519984133

Prowse, S. D. (1992). The Structure of Corporate Ownership in Japan. Journal of Finance, 47(3), 1121-1140. https://doi.org/10.1111/j.1540-6261.1992.tb04007.x

Rafael, L. P., Lopez-De-Silanes, F., Shleifer, A., \& Vishny, R. (1999). Corporate Ownership Around the World. Journal of Finance, 54(2), 471-518. https://doi.org/10.1111/0022-1082.00115

Renneboog, L. (2000). Ownership, Managerial Control and the Governance of Companies Listed on the Brussels Stock Exchange. Journal of Banking \& Finance, 24(12), 1959-1995. 
https://doi.org/10.1016/S0378-4266(99)00128-4

Shleifer, A., \& Vishny, R. W. (1986). Large Shareholders and Corporate Control. The Journal of Political Economy, 94(3), 461-488. https://doi.org/10.1086/261385

Shleifer, A., \& Vishny, R. W. (1997). A Survey of Corporate Governance. Journal of Finance, 52(2), $737-783$. https://doi.org/10.1111/j.1540-6261.1997.tb04820.X

Slovin, M. B., \& Sushka, M. E. (1993). Ownership Concentration, Corporate Control Activity, and Firm Value: Evidence from the Death of Inside Blockholders. Journal of Finance, 48(4), 1293-1321. https://doi.org/10.1111/j.1540-6261.1993.tb04755.x

Stevens, J. (2002). Applied Multivariate Statistics for the Social Sciences. Lawrence Erlbaum.

Thomsen, S., Pedersen, T., \& Kvist, H. K. (2006). Blockholder Ownership: Effects on Firm Value in Market and Control Based Governance Systems. Journal of Corporate Finance, 12(2), 246-269. https://doi.org/10.1016/j.jcorpfin.2005.03.001

Yeo, G. H. H., Tan, P. M. S., Ho, K. W., \& Chen, S. S. (2002). Corporate Ownership Structure and the Informativeness of Earnings. Journal of Business Finance \& Accounting, 29(7-8), 1023-1046. https://doi.org/10.1111/1468-5957.00460

Zeckhauser, R. J., \& Pound, J. (1990). Are Large Shareholders Effective Monitors? An Investigation of Share Ownership and Corporate Performance. University of Chicago Press, 1990.

Zhuang, J. (2001). Corporate Governance and Finance in East Asia: A Study of Indonesia, Republic of Korea, Malaysia, Philippines, and Thailand (Vol. 2). Asian Development Bank.

\section{Notes}

Note 1. Dual class share represents two classes of shares with different voting rights under same ownership.

Note 2. An individual or a group investor who buys a large fraction of publicly held companies shares. 